\title{
AN UNKNOWN FRENCH WHITMANIAC
}

\author{
Roger Asselineau
}

No BIBLIOGRAPHY OR BOOK on the reputation of Leaves of Grass in France describes or even lists a thin pamphlet of seventy pages which appeared in Paris in November 1934 under the title of Whitmaniana. ${ }^{1}$ The author was an unknown writer, one R. de Maratray. The pamphlet belonged to a series of monthly publications called Bibliothèque de l'Artistocracie (not to be confounded with "aristocratie," the cover blurb warns us). The purpose of the publisher (the equally unknown Gérard de LacazeDuthiers) was to provide subscribers with an "encyclopedia of contemporary thought." It was an eclectic series. The subtitle of Whitmaniana was "Réflexions d'un adepte de la morale 'ouverte." This "morale" was in principle open to all, but it was actually biased towards the Left. Among the contributors were authors like Han Ryner (a well-known anarchist), Georges Pioch (a well-known pacifist), Victor Margueritte, Victor Basch (the President of the "Ligue des Droits de l'Homme"), E. Armand (who later became the editor of an anarchist monthly, L'Unique), ${ }^{2}$ and Gabriel Sarrazin (who had published an excellent essay on Whitman in La Renaissance de la Poésie Anglaise, 1798-1889). ${ }^{3}$

The cover and the title-page of Whitmaniana carry an epigraph borrowed from Whitman- "La question essentielle à poser relativement à un livre est celle-ci: 'A-t-il fortifié aucune âme humaine?" - which is the translation of a passage in Democratic Vistas: "The true question to ask respecting a book, is, Has it helped any human soul?" (Actually Whitman was here quoting with approval the Librarian of Congress speaking before the Social Science Convention in New York, in October, 1869.) ${ }^{4}$

The book opens with a two-page introductory chapter entitled " $\mathrm{La}$ Mission du Poète":

Aime la terre, le soleil et les animaux,

$\mathrm{Ne}$ deviens pas la proie des richesses,

Donne à toute main tendue,

Protège le stupide et le fou,

Consacre à autrui ton revenu et ton travail,

Déteste la tyrannie,

Ne discute point Dieu,

Sois patient et indulgent envers tout le monde,

Ne t'abaisse devant rien de connu ou d'inconnu, ni devant aucun homme ou groupe

d'hommes,

Refais l'examen de tout ce que t'ont dit les écoles, les églises ou les livres, 
Et répudie tout ce qui peut faire injure à ton âme.

Alors ta propre chair sera comme un grand poèmes, et une fluide générosité rayonnera non-seulement de tes paroles mais des lignes silencieuses de ta bouche et de ton visage et à travers tes cil et dans chaque mouvement de tes membres et de ton corps.

A footnote specifies that this is a translation of one of Whitman's poems, "To the maker of poems." But where did de Maratray find this unknown poem? He does not say. Actually, it is a free translation of a passage in the 1855 Preface of Leaves of Grass:

This is what you shall do: Love the earth and sun and the animals, despise riches, give alms to every one that asks, stand up for the stupid and crazy, devote your income and labor to others, hate tyrants, argue not concerning God, have patience and indulgence toward the people, take off your hat to nothing known or unknown or to any man or number of men, ... re-examine all you have been told at school or church or in any book, dismiss whatever insults your own soul, and your very flesh shall be a great poem and have the richest fluency not only in its words but in the silent lines of its lips and face and between the lashes of your eyes and in every motion and joint of your body. ${ }^{5}$

This introductory poem is the starting-point, the text, so to speak, on which de Maratray builds the lay sermon which follows. Each of the first eleven lines which make up the poem becomes in its turn the title of a chapter, and each chapter is an extrapolation of one of Whitman's lines. The first chapter thus expatiates on the poet's love of the physical world: the earth and the sun, men, and especially animals. The author insists there is no reason for excluding animals, and, in order to emphasize the point, quotes the beginning of Section 32 of "Song of Myself" ("I think I could turn and live with animals . .."), which he translates in rhymed verse, without realizing that it is a sort of treason to do so. $\mathrm{He}$ also quotes an unpublished poem by his grandfather, J. FournierMaratray, to prove the fundamental good will of lions towards all men.

In the rest of the book, de Maratray similarly develops Whitman's thought, while extrapolating his own views. He approves of Whitman's religious inclusiveness and, like him, puts Jesus and Buddha in the same portfolio, but he denounces the anthropomorphism and anthropocentrism of all established religions. To those who ask if God exists, he answers that only God exists and only the spirit is imperishable, thus undercutting Whitman's emphasis on the value and importance of matter. As a result, he emphasizes the spiritualism of Ouspensky in his Tertium Organum. For him there are two races of men: those who are endowed with "cosmic consciousness" (he uses R. M. Bucke's phrase), and those who belong to the unenlightened masses. His ideal is the man "who sees the cosmos in the smallest leaf of grass."

Politically, de Maratray offers more practical and down-to-earth solutions than Whitman, for he believes in syndicalism and more par- 
ticularly in Fourierism (and in Fourier's phalansteries). More presciently than Whitman, and helped in this respect by his knowledge of twentieth-century historical developments, he sees the dangers inherent in all forms of collectivism. He equally condemns nazism, fascism and communism and exalts Krishnamurti, who, like Whitman, recommends against following any leader blindly and says we should acknowledge no master. For de Maratray, the source of all evils is greed, the universal worship of the Golden Calf, which even the masses are only too often inclined to practice. In short, contrary to Whitman, he does not believe in the "divine average." He so thoroughly distrusts the masses and is so afraid of "le roi-Foule" ("King-Mob") that he is willing to accept compromises. He thus praises the enlightened philanthropy of American magnates (Whitman, after all, did so too), and he has more faith in their policy of high wages and redistribution of wealth than in utopian experimentation, which he believed would lead sooner or later to some form of tyranny and exploitation.

Such are the main points touched upon by de Maratray in his Whitmaniana, inspired by Whitman but nonetheless original in several respects and produced for consumption by a readership of hard-headed French syndicalists who had no confidence in the capitalist press and the easily influenced masses living in large unhealthy "metropoles like Berlin, New York or Paris." De Maratray was finally a disappointed journalist with no Whitmanian faith in "the Hoe press whirling its cylinders, shedding the printed leaves steady and fast" $(L G, 200)$.

\section{Université de Paris-Sorbonne}

\section{NOTES}

1 R. de Maratray. Whitmaniana-Réflexions d'un adepte de la morale "ouverte" (Paris: Les Ecrivains Indépendants, 1934). $71 \mathrm{pp}$.

2 Armand was present at the Sorbonne when I defended my dissertation on "The Evolution of Walt Whitman," and he later wrote an article about it, "Resurrexit Walt Whitman," in L'Unique 11 (January/February 1955), 16-18.

3 Whitman liked Sarrazin's article very much. It was translated by Harrison S. Morris and published in Horace Traubel, Richard Maurice Bucke, and Thomas B. Harned, eds., In Re Walt Whitman (Philadelphia: David McKay, 1893), 159-194.

4 See Floyd Stovall, ed., Prose Works 1892 (New York: New York University Press, 1964), 2:420.

5 Walt Whitman. Leaves of Grass: Comprehensive Reader's Edition, ed. by Harold W. Blodgett and Sculley Bradley (New York: New York University Press, 1965), 714715. Whitman later incorporated this passage, with slight formal changes, in "By Blue Ontario's Shore," Section 14 (p. 351). 